\title{
THERMAL ANALYSIS OF A SMALL SCALE SOLID WASTE-FIRED STEAM BOILER FOR POWER GENERATION IN BENIN CITY, NIGERIA
}

\author{
E. P. Akhator ${ }^{1,}$, A. I. Obanor ${ }^{2}$ and D. I. Igbinomwanhia ${ }^{3}$ \\ 1,2,3 Department of Mechanical EngineERING, University of Benin, Benin City, Edo State. NiGERIA. \\ E-mail addresses:1akhatorpeter@yahoo.com,2aiobanor@yahoo.com,3digbinomwanhia@uniben.edu
}

\begin{abstract}
Thermal analysis of a small scale solid waste-fired steam generator is presented in this paper. The analysis was based on the chosen design specifications which are operating steam pressure and temperature of $20 \mathrm{bar}$ and $400^{\circ} \mathrm{C}$ respectively, solid waste consumption rate of $3.6 \mathrm{ton} / \mathrm{hr}$ and a furnace utilizing grate-fired technology. The boiler is designed as a possible waste management option in Benin Metropolis and Nigeria at large with energy recovery. The average daily municipal solid waste (MSW) generation in Benin Metropolis was considered in order to assess the availability of the feed stock. A calorific value of $17.49 \mathrm{MJ} / \mathrm{kg}$ was obtained for the solid waste using Dulong's formula. Calculations based on energy balance in the boiler show that about $7.63 \mathrm{~kg} / \mathrm{s}$ of air is required to combust $1 \mathrm{~kg} / \mathrm{s}$ of $M S W$ to produce about $3.437 \mathrm{~kg} / \mathrm{s}$ of steam. Further calculations show that about $1.4 M W$ of electrical power can be obtained from the produced steam.
\end{abstract}

Keywords: Solid waste combustion, Solid waste management, Calorific value, Steam boiler, Waste-to-energy.

\section{Nomenclature}

$\mathrm{A}_{\mathrm{f}} \quad$ cross sectional area of furnace $\left(\mathrm{m}^{2}\right)$

$\mathrm{Cp}_{\mathrm{fg}}$ specific heat capacity of flue gas at constant pressure $(\mathrm{kJ} / \mathrm{kgK})$

$\mathrm{CV}_{\text {sw }}$ calorific value of solid waste $(\mathrm{kJ} / \mathrm{kg})$

$\dot{\mathrm{m}}_{\mathrm{sw}}$ solid waste mass flow $(\mathrm{kg} / \mathrm{s})$

$\dot{\mathrm{m}}_{\text {air }}$ air mass flow $(\mathrm{kg} / \mathrm{s})$

$\dot{\mathrm{m}}_{\mathrm{s}} \quad$ steam mass flow rate $(\mathrm{kg} / \mathrm{s})$

$\mathrm{P}_{\mathrm{e}} \quad$ electrical power $(\mathrm{kW})$

$\mathrm{p}$ condenser pressure (bar)

$\mathrm{Q}_{\mathrm{f}} \quad$ heat released by solid waste $(\mathrm{kW})$

$\mathrm{Q}_{\mathrm{s}} \quad$ heat absorbed by steam $(\mathrm{kW})$

$\mathrm{T}$ temperature $(\mathrm{K})$

$\dot{\mathrm{W}}_{\mathrm{t}} \quad$ turbine work $(\mathrm{kJ} / \mathrm{kg})$

$\dot{\mathrm{W}}_{\mathrm{p}} \quad$ pump work $(\mathrm{kJ} / \mathrm{kg})$

$\alpha_{\mathrm{e}} \quad$ enthalpy of expanded steam (kJ/kgK)

$\alpha_{\mathrm{s}} \quad$ enthalpy of steam $(\mathrm{kJ} / \mathrm{kgK})$

$\alpha_{\mathrm{w}} \quad$ enthalpy of water $(\mathrm{kJ} / \mathrm{kgK})$

$\eta_{\mathrm{ti}} \quad$ turbine isentropic efficiency (\%)

$\eta_{\mathrm{p}} \quad$ pump isentropic efficiency (\%)

$\eta_{\text {gen }}$ generator efficiency (\%)

$\eta_{t m}$ turbine shaft mechanical efficiency (\%) $\eta_{b} \quad$ boiler thermal efficiency (\%)

\section{INTRODUCTION}

Over the years, the development of technologies to utilize renewable energy sources for power generation has become imperative. Despite the advancement achieved on the energy front in the last 20 years, 1.7 billion people are still without access to electricity [1]. With the present impact by greenhouse gas emission, depleting of conventional fuel reserves, increasing demand of energy, rapid population and economic growth rates, health problems from air pollution, etc., the UN General Assembly in 2011 aimed to achieve three clear objectives by 2030 . These are ensuring universal access to modern energy service, doubling the global rate of improvement in energy efficiency, and doubling the share of renewable energy in the global energy mix [2].

Since the emergence and need for sustainability, different renewable energy technologies have been investigated and developed for the production of electricity. These renewable energy technologies include: wind, bio-energy, geothermal, solar thermal, hydro, and photovoltaic, etc. [3]. Biomass as bioenergy source has been cited as the world's largest 
renewable energy source and its resources are distributed around the world [4]. Biomass resources are considered renewable because they occur naturally and when properly managed, may be harvested without significant depletion.

Furthermore, in improving the energy efficiency and energy accessibility for sustainable energy for all platforms set by the United Nations, small-scale power technology is seen as an efficient way in achieving this goal. Clean energy from biomass can be realized ranging from small-scale processing plant to an industrial scale. Decentralization of energy distribution via small-scale set ups have several merits which include positive impact on rural development, ease of operation, high economic incentives, reduction of energy loss via transmission, encourages green economy and energy independence, etc. Compared to many other renewable energy options, biomass has the advantage of dispatchability, implying it is controllable and available when needed, similar to fossil fuel electric generation systems [5].

There are several methods to generate energy from biomass and these include thermal, physical, biological and chemical methods. These methods could convert biomass to heat, electricity, liquid fuels (such as bio-oils, ethanol and methanol) and gaseous fuels (such as hydrogen and syngas), respectively [6]. Thermal technologies used to recover energy from solid waste are generally classified as either conventional combustion or advanced thermal technologies [7]. Conventional combustion includes grate-fired and fluidized bed technologies. Despite the fact that fluidized bed technology is commonly applied, grate-fired technology is preferred when it comes to small-scale application, handling of solid fuels that have varying or even higher moisture content and it does not require extensive preprocessing of the fuels. Energy recovery is achieved through the production of steam in boiler superheater tubes. The steam may be utilized to generate electricity in a steam turbine generator or sold directly for commercial or process heat purposes. The heat content of steam exiting the steam turbine generators can also be used for district heating purposes.

The utilization of biomass for electricity generation has already been established, for example in Sweden in 2010 there were 32 waste-to-energy (WTE) plants. These plants combust an estimated 5.1million tonnes of solid waste generated annually to produce about $1.6 \mathrm{TWh}$ of electricity per year and a clean environment for her citizens to live in [8]. In Nigeria about 25 million tonnes of solid waste are generated annually [9]. With about 14 million tonnes available for combustion in WTE plants [10], these solid wastes could generate about 4.4TWh of electricity per year and their combustion in this manner could assist in the effort to provide an aesthetic environment in the country. The electricity generated would greatly complement the current grid electricity, reduce the number of hours that electricity is unavailable and boost economic activities in Nigeria. Adopting WTE technology in Nigeria would contribute to achieving the goals of Nigeria's Renewable Energy Master Plan (REMP), which is to have biomass-based power plants with installed capacity of 50MW in 2015 and 400MW in 2025 [11]. WTE technology could portend electrical energy independence for most private companies and tertiary institutions that before now have to spend huge extra sums of money on diesel generators despite already paying huge amount for grid electricity. With the power sector now privatized, WTE technology could present the generation companies a cheap alternative source for generating electrical energy. Additionally, the streets of Nigeria will be cleaner and healthier by combusting her solid waste in WTE plants.

According to [12], about 19 thousand tonnes of solid waste are generated annually in Benin Metropolis. With the grate-fired technology, about $6.1 \mathrm{GWh}$ could be harnessed annually from this quantity of waste. This quantity of electrical power would contribute hugely to satisfying the electricity need of Benin Metropolis. Such solid waste utilization would enhance cleanliness in the metropolis. This paper presents thermal analysis of a steam boiler with feedstock from combustible solid waste.

\section{METHODOLOGY}

\subsection{Daily Municipal Solid Waste Generation in Benin Metropolis}

Table 1 shows the average daily solid waste generation in Benin metropolis. According to [13], population of Benin Metropolis is 1,085,676. Therefore, total solid waste generated per day $=0.358$ $\times 1,085,676=388,672.008 \mathrm{~kg}$ and total combustible solid waste per day $=0.049 \times 1,085,676=$ $53,198.124 \mathrm{~kg}$.

\subsection{Combustion Analysis of Municipal Solid Waste (MSW)} Municipal solid waste contains the following elements: c kg of carbon (C), h $\mathrm{kg}$ of hydrogen $\left(\mathrm{H}_{2}\right)$, o $\mathrm{kg}$ of 
oxygen $\left(\mathrm{O}_{2}\right), \mathrm{n}$ kg of nitrogen $\left(\mathrm{N}_{2}\right), \mathrm{s} \mathrm{kg}$ of sulphur $(\mathrm{S})$, $\mathrm{m}$ kg of moisture, a kg of ash. $\mathrm{c}+\mathrm{h}+0+\mathrm{n}+\mathrm{s}+\mathrm{m}+$ $\mathrm{a}=1 \mathrm{~kg}$ of fuel (MSW) [14].

Water and nitrogen are found in gaseous form after combustion. The ash does not participate in the combustion process. The oxygen contained in the fuel gives a negative contribution to the demand of oxygen for combustion. The theoretical combustion reaction formulae of the combustible elements of municipal solid waste are expressed by the following equations:

$$
\begin{aligned}
& \mathrm{C}+\left[\mathrm{O}_{2}+(79 / 21) \mathrm{N}_{2}\right] \\
& \quad \rightarrow \mathrm{CO}_{2}+(79 / 21) \mathrm{N}_{2} \\
& \mathrm{H}_{2}+05\left[\mathrm{O}_{2}+(79 / 21) \mathrm{N}_{2}\right] \\
& \quad \rightarrow \mathrm{H}_{2} \mathrm{O}+0.5(79 / 21) \mathrm{N}_{2} \\
& \mathrm{~S}+\left[\mathrm{O}_{2}+(79 / 21) \mathrm{N}_{2}\right] \rightarrow \mathrm{SO}_{2}+(79 / 21) \mathrm{N}_{2}
\end{aligned}
$$

The mass balance in the combustion chamber can be expressed as shown in Figure 1 in the form:

$$
\dot{\mathrm{m}}_{\text {in }}=\dot{\mathrm{m}}_{\text {out }}
$$

Table1: Average components of household solid waste generated per person per day.

\begin{tabular}{lc}
\hline Components & Mass(kg) \\
\hline Food waste & 0.281 \\
Plastic/rubber & 0.031 \\
Paper & 0.015 \\
Metal waste & 0.012 \\
Glass & 0.008 \\
Other waste & 0.003 \\
Total Solid Waste & 0.358 \\
\hline
\end{tabular}

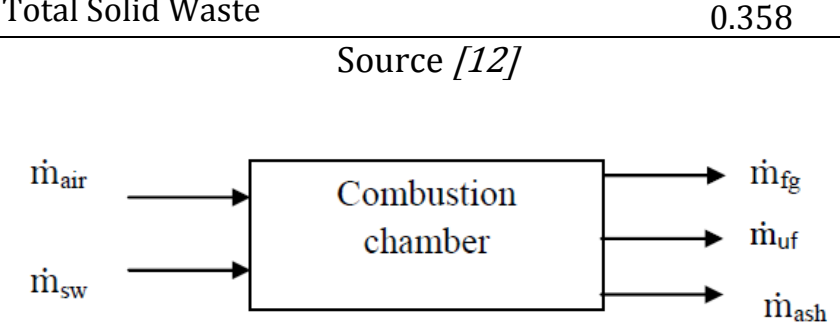

Figure 1: Mass balance in the combustion chamber.

$\dot{\mathrm{m}}_{\mathrm{sw}}+\dot{\mathrm{m}}_{\mathrm{air}}=\dot{\mathrm{m}}_{\mathrm{fg}}+\dot{\mathrm{m}}_{\mathrm{ash}}+\dot{\mathrm{m}}_{\mathrm{uf}}$

$\Rightarrow \dot{\mathrm{m}}_{\mathrm{air}}=\left(\dot{\mathrm{m}}_{\mathrm{fg}}+\dot{\mathrm{m}}_{\mathrm{ash}}+\dot{\mathrm{m}}_{\mathrm{uf}}\right)-\dot{\mathrm{m}}_{\mathrm{sw}}$

$\dot{\mathrm{m}}_{\mathrm{fg}}=\left(\dot{\mathrm{m}}_{\mathrm{sw}}+\dot{\mathrm{m}}_{\mathrm{air}}\right)-\left(\dot{\mathrm{m}}_{\mathrm{ash}}+\dot{\mathrm{m}}_{\mathrm{uf}}\right)$

Amount of theoretical air $\left(\dot{\mathrm{m}}_{\mathrm{air}}{ }^{\text {th }}\right)$ can be calculated as follows:

$\dot{\mathrm{m}}_{\text {air }}{ }^{\text {th }}=\mathrm{O}_{2}$ required per kg of solid waste $/ 23.3 \%$ of

$\mathrm{O}_{2}$ in air, where, air is assumed to contain $23.3 \%$ of $\mathrm{O}_{2}$ by mass.

$$
\begin{array}{rl} 
& \frac{\mathrm{c}}{12.01}+\frac{0.5 \mathrm{~h}}{2.016}+\frac{\mathrm{s}}{32.06}-\frac{\mathrm{o}}{32} \\
0.233 & 0.357 \mathrm{c}+1.064 \mathrm{~h}+0.134 \mathrm{~s}-0.134 \mathrm{o}
\end{array}
$$

Substituting eqn. (7) into eqn. (5c), the mass of flue gas per kg of solid waste can be obtained as follows:

$$
\begin{aligned}
\frac{\dot{\mathrm{m}}_{\mathrm{fg}}}{\dot{\mathrm{m}}_{\mathrm{sw}}}=(0.357 \mathrm{c} & +0.134 \mathrm{~s}-0.134 \mathrm{o}) \\
& +\left(1-\frac{\dot{\mathrm{m}}_{\mathrm{ash}}}{\dot{\mathrm{m}}_{\mathrm{sw}}}-\frac{\dot{\mathrm{m}}_{\mathrm{uf}}}{\dot{\mathrm{m}}_{s w}}\right)
\end{aligned}
$$

With excess air,

$$
\begin{gathered}
\frac{\dot{\mathrm{m}}_{\mathrm{air}}}{\dot{\mathrm{m}}_{\mathrm{sw}}}=(1+\alpha)(0.357 \mathrm{c}+1.064 \mathrm{~h}+0.134 \mathrm{~s} \\
-0.134 \mathrm{o})
\end{gathered}
$$

and

$$
\begin{aligned}
& \frac{\dot{\mathrm{m}}_{\mathrm{fg}}}{\dot{\mathrm{m}}_{\mathrm{sw}}}=(1+\alpha)(0.357 \mathrm{c}+1.064 \mathrm{~h}+0.134 \mathrm{~s}-0.134 \mathrm{o}) \\
& +\left(1-\frac{\dot{\mathrm{m}}_{\mathrm{ash}}}{\dot{\mathrm{m}}_{\mathrm{sw}}}-\frac{\dot{\mathrm{m}}_{\mathrm{uf}}}{\dot{\mathrm{m}}_{s w}}\right)
\end{aligned}
$$

Where, $(1+\alpha)$ is the excess air ratio.

\section{CALCULATION OF COMBUSTION AIR AMOUNT}

Nitrogen reacts with oxygen to form $\mathrm{NO}_{\mathrm{x}}$ at about $1200^{\circ} \mathrm{C}$ and above [15]. In this study, the upper limit of flue gas temperature is assumed as $1150^{\circ} \mathrm{C}$. So, nitrogen is not considered to react with oxygen during the combustion reaction. It limits the intimacy between the fuel molecules and oxygen [15]. Table 2 shows the ultimate analysis of the combustible fraction of MSW.

Considering the theoretical combustion reaction for the elemental analysis of MSW, yields

\begin{tabular}{llllll}
$\mathrm{C}$ & $\mathrm{O}_{2}$ & $\rightarrow$ & $\mathrm{CO}_{2}$ & & $(10)$ \\
$12.01 \mathrm{~kg}$ & & $32.00 \mathrm{~kg}$ & & $44.01 \mathrm{~kg}$ & \\
$0.47025 \mathrm{~kg}$ & & $1.25296 \mathrm{~kg}$ & & $1.72321 \mathrm{~kg}$ & \\
\hline $\mathrm{H}_{2}$ & + & $0.5 \mathrm{O}_{2}$ & $\rightarrow$ & $\mathrm{H}_{2} \mathrm{O}$ & $(11)$ \\
$2.016 \mathrm{~kg}$ & & $16.00 \mathrm{~kg}$ & & $18.016 \mathrm{~kg}$ & \\
$0.05175 \mathrm{~kg}$ & & $0.41071 \mathrm{~kg}$ & & $0.46246 \mathrm{~kg}$ & \\
\hline $\mathrm{S}$ & $\mathrm{O}_{2}$ & $\rightarrow$ & $\mathrm{SO}_{2}$ & $(12)$ \\
$32.06 \mathrm{~kg}$ & & $32.00 \mathrm{~kg}$ & & $64.06 \mathrm{~kg}$ & \\
$0.0009 \mathrm{~kg}$ & $0.0008983 \mathrm{~kg}$ & & $0.0017983 \mathrm{~kg}$ &
\end{tabular}

Assuming 30\% excess air,

$$
\dot{\mathrm{m}}_{\mathrm{air}} \cdot=\mathrm{m}_{\mathrm{air}}{ }^{\text {th }}(1+\alpha)
$$

The calorific value of MSW was calculated using Dulong's formula [17] and elemental analysis of MSW given in Table 2.

$$
\begin{gathered}
\mathrm{CV}_{\mathrm{sw}}=0.339 \mathrm{C}+0.105 \mathrm{~S}+1.21(\mathrm{H}-0.1250) \\
-0.0251 \mathrm{H}_{2} \mathrm{O}
\end{gathered}
$$

\section{BOILER CALCULATIONS}

\subsection{Boiler Efficiency}

There are two methods of calculating boiler efficiency: the direct and indirect methods [18]. 
Table 2: Ultimate analysis of MSW on a percentage by mass

\begin{tabular}{|c|c|c|c|c|c|c|c|}
\hline Element & $\mathrm{C}$ & $\mathrm{H}$ & $\mathrm{S}$ & $\mathrm{O}$ & $\mathrm{N}$ & Moisture & Ash \\
\hline Percentage & 47.025 & 5.175 & 0.09 & 29.700 & 1.620 & 10.000 & 6.390 \\
\hline
\end{tabular}

Source [16]

In the direct method, the boiler efficiency is directly defined by the useful heat output from the boiler and the heat input to the boiler obtained by burning fuel; it is expressed as [18]:

$$
\eta_{\mathrm{b}}=\frac{\mathrm{Q}_{\mathrm{s}}}{\mathrm{Q}_{\mathrm{f}}}
$$

The indirect method determines the efficiency of a boiler by the sum of the major heat losses and the heat input to the boiler as expressed below [18]

$$
\eta_{\mathrm{b}}=1-\frac{\mathrm{Q}_{\text {losses }}}{\mathrm{Q}_{\mathrm{f}}}
$$

Though, the indirect method provides a better understanding of the effect of individual losses on the boiler efficiency [18], the direct method was used in this work to determine the boiler efficiency due to insufficient information on the actual losses in the boiler being analysed. From (16),

$$
\mathrm{Q}_{\mathrm{s}}=\dot{\mathrm{m}}_{\mathrm{s}}\left(\alpha_{\mathrm{s}}-\alpha_{\mathrm{w}}\right)
$$

and

$$
\mathrm{Q}_{\mathrm{f}}=\dot{\mathrm{m}}_{\mathrm{sw}} \mathrm{CV}_{\mathrm{sw}}
$$

\subsection{Furnace Heat Flux}

The average heat flux,q, in the furnace is given by [14]

$$
q=\frac{Q_{s}}{A_{f}}
$$

\subsection{Equivalent Evaporation of Boiler}

This is the amount of water evaporated at $100^{\circ} \mathrm{C}$, forming dry and saturated steam at $100^{\circ} \mathrm{C}$ at normal atmospheric pressure. As the water is already at the boiling temperature, it requires only latent heat at 1.013 bar to convert it into steam at $100^{\circ} \mathrm{C}$. The value of this latent heat is taken as $2257 \mathrm{~kJ} / \mathrm{kg}$. Thus, the equivalent evaporation, $\mathrm{E}$, of a boiler from and at $100^{\circ} \mathrm{C}$ is given by [18]

$$
\mathrm{E}=\frac{\dot{\mathrm{m}}_{\mathrm{r}}\left(\alpha_{\mathrm{s}}-\alpha_{\mathrm{w}}\right)}{2257}
$$

In (20), $\dot{\mathrm{m}}_{\mathrm{r}}=\dot{\mathrm{m}}_{\mathrm{s}} / \dot{\mathrm{m}}_{\mathrm{sw}}$ and $\left(\alpha_{\mathrm{s}}-\alpha_{\mathrm{w}}\right) / 2257$ is known as factor of evaporation, and its value is always greater than one for all boilers.

\subsection{Electrical Power Generation}

The temperature - entropy $(\mathrm{T}-\mathrm{s})$ diagram for the processes in the solid waste steam boiler (SWSB) power plant is shown in Figure 3.
Pressure of steam at turbine inlet, $\mathrm{p}_{4}=20 \mathrm{bar}$ (given), Temperature of steam at turbine inlet, $t_{4}=400^{\circ} \mathrm{C}$ (given), Pressure of steam at turbine outlet, $\mathrm{p}_{5}=$ $0.1 \mathrm{bar}$ (assumed). Specific enthalpy and entropy of steam at turbine inlet are obtained from [19]:

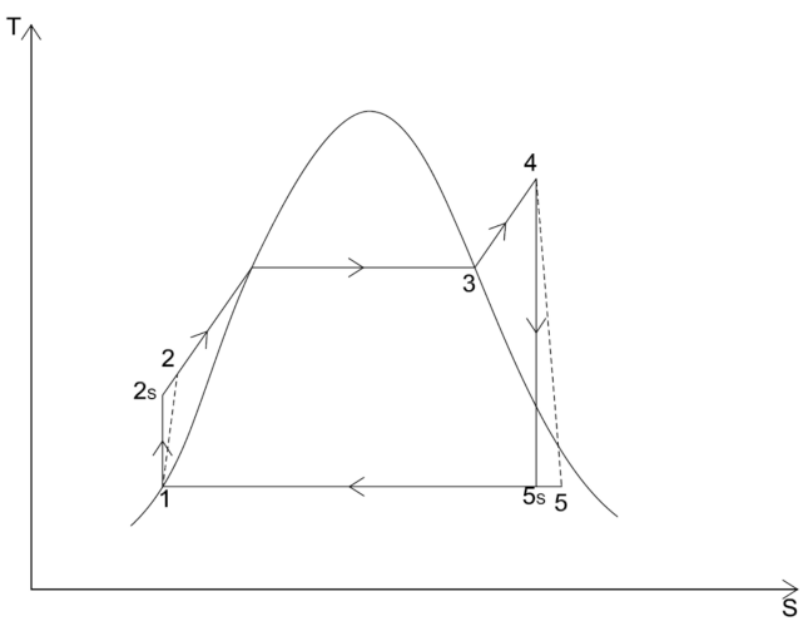

Figure 2: T-s diagram of the SWSB plant.

$$
\mathrm{S}_{5 \mathrm{~s}}=\mathrm{f}_{\mathrm{f} 5}+\mathrm{x}_{5 \mathrm{~s}} \cdot \mathrm{S}_{\mathrm{fg} 5}
$$

Where, $\mathrm{x}$ is the dryness fraction of the steam. Similarly,

$$
\begin{aligned}
& h_{5_{3}}=h_{f 5}+X_{5_{3}} h_{f g 5} \\
& \eta_{t i}=\frac{h_{4}-h_{5}}{h_{4}-h_{5 s}}
\end{aligned}
$$

In (27), $\mathrm{h}_{5}$ is actual enthalpy of steam at turbine outlet. Small, single stage steam turbines can have efficiencies as low as $50 \%$ [21]. Thus $\eta_{\mathrm{ti}}$ is assumed to be 0.5 .

$$
\mathrm{W}_{\mathrm{t}}=\mathrm{h}_{4}-\mathrm{h}_{5}
$$

Ideal pump work is given by:

$$
\mathrm{W}_{\mathrm{p}}=\frac{\mathrm{P}_{2}-\mathrm{P}_{1}}{\rho_{f} \times \eta_{p}}
$$

The electrical power obtainable from the produced steam is given by [20]:

$$
\mathrm{P}_{\mathrm{e}}=\mathrm{m}_{\mathrm{s}}\left(\dot{\mathrm{W}}_{\mathrm{t}}-\dot{\mathrm{W}}_{\mathrm{p}}\right) \times \eta_{\mathrm{m}} \times \eta_{\text {gen }}
$$

\section{RESULTS AND DISCUSSION}

The parameters used and those obtained by utilising the thermal analysis equations are presented in Table 3. The variation of the calorific value of solid waste with different values of moisture content is shown in Figure 3. 
Table 3: Parameters used and those obtained from the thermal analysis equations

\begin{tabular}{|c|c|c|c|c|c|c|c|}
\hline \multicolumn{2}{|c|}{ Mass flowrate $(\mathrm{kg} / \mathrm{s})$} & \multicolumn{2}{|c|}{ Enthalpy/ Work (kJ/kg) } & \multicolumn{2}{|c|}{ Temperature $\left({ }^{\circ} \mathrm{C}\right)$} & \multicolumn{2}{|c|}{ Heat $(\mathrm{kW})$} \\
\hline$\dot{\mathrm{m}}_{\mathrm{sw}}$ & 1.000 & $\alpha_{s}$ & 3248.000 & $\mathrm{~T}_{\text {fgi }}$ & 705.000 & $\mathrm{Q}_{\mathrm{f}}$ & 17490.000 \\
\hline$\dot{\mathrm{m}}_{\text {air }}$ & 7.630 & $\alpha_{w}$ & 194.490 & $\mathrm{~T}_{\mathrm{fgo}}$ & 200.000 & $\mathrm{Q}_{\mathrm{s}}$ & 10494.914 \\
\hline$\dot{\mathrm{m}}_{\mathrm{fg}}$ & 8.566 & $\alpha_{e}$ & 2752.865 & $\mathrm{~T}_{\mathrm{s}}$ & 400.000 & \multicolumn{2}{|c|}{ Power $(\mathrm{kW})$} \\
\hline \multirow[t]{2}{*}{$\dot{\mathrm{m}}_{\mathrm{s}}$} & 3.437 & $\dot{\mathrm{W}}_{\mathrm{t}}$ & 495.135 & $\mathrm{~T}_{\mathrm{w}}$ & 46.036 & $\mathrm{P}_{\mathrm{e}}$ & 1351 \\
\hline & & $\dot{\mathrm{W}}_{\mathrm{p}}$ & 2.513 & & & & \\
\hline \multicolumn{8}{|c|}{ Efficiency (\%) } \\
\hline$\eta_{b}$ & 60 & $\eta_{t m}$ & 84 & $\eta_{t i}$ & 50 & $\eta_{p}$ & 80 \\
\hline$\eta_{\text {gen }}$ & 95 & & & & & & \\
\hline \multicolumn{8}{|c|}{ Other Parameters } \\
\hline $\mathrm{CV}_{\mathrm{sw}}[\mathrm{kJ} / \mathrm{kg}]$ & 17490 & $\mathrm{E}$ & 4.6499 & $\mathrm{Cp}_{\mathrm{fg}}[\mathrm{kJ} / \mathrm{kgK}]$ & 1.3067 & $\mathrm{q}\left(\mathrm{kW} / \mathrm{m}^{2}\right)$ & 6996.609 \\
\hline $\mathrm{p}(\mathrm{bar})$ & 0.1 & $\mathrm{~A}_{\mathrm{f}}\left[\mathrm{m}^{2}\right]$ & 1.5000 & & & & \\
\hline
\end{tabular}

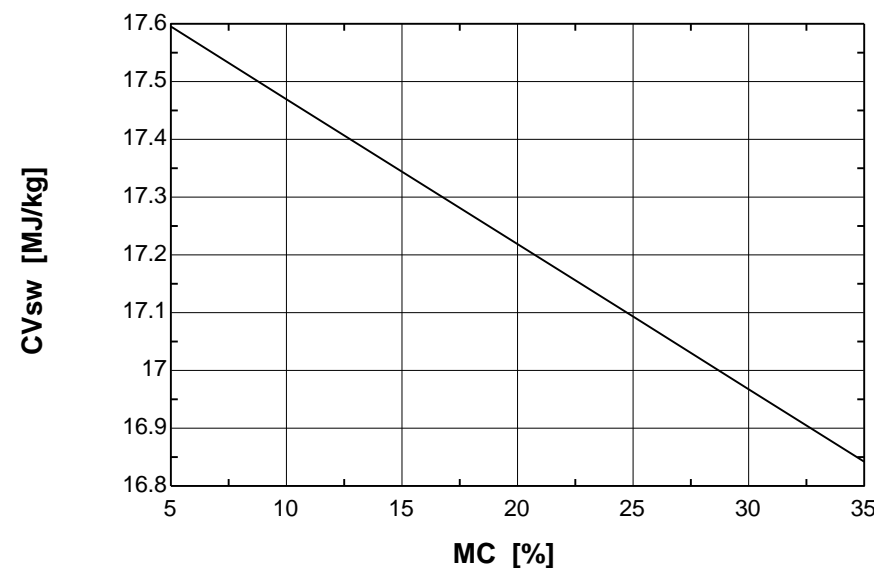

Figure 3: Variation of calorific value of the solid waste with different values of moisture content.

The drying characteristics of solid waste depend on their moisture contents. Those with higher moisture content require longer time and more energy to dry them, thereby reducing the amount of heat available from the waste and thus resulting in lower temperature in the furnace.

The reverse is the case for solid waste with lower moisture content. If the moisture content is too high, the furnace temperature achieved will be too low to sustain combustion, hence an auxiliary fuel will be needed to raise the temperature and ensure normal combustion. To evaluate the effect of moisture on the combustion process, numerical simulation and analysis were carried out using seven different values of moisture content. The Engineering Equation Solver (EES) developed at University of Wisconsin was used for the analysis. The results of the analysis show that the lower the moisture content in solid waste the higher its heating value and hence higher temperatures in the furnace. Hence, for better boiler efficiency, the solid wastes should be dried before being fed into the furnace. Figure 4 shows the changes

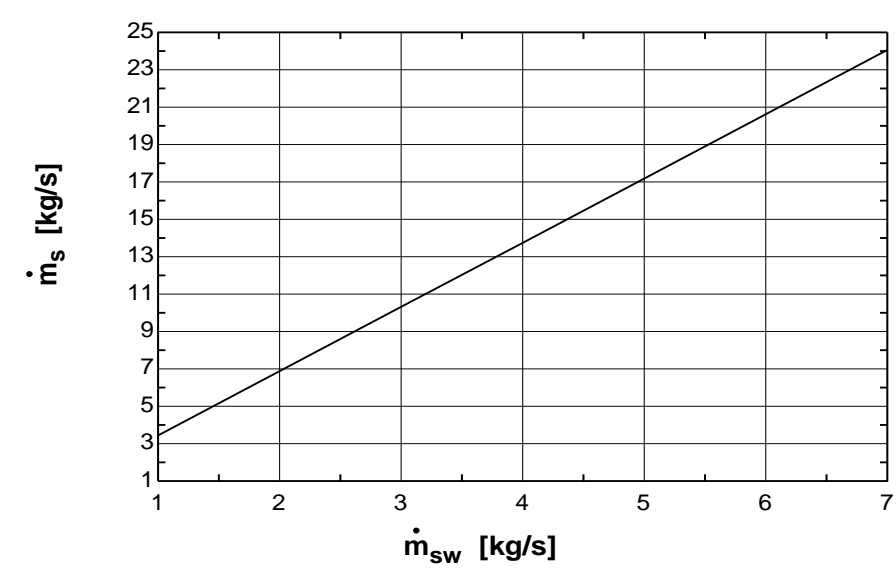

Figure 4: Changes in the quantity of steam generated in relation to amount of solid waste combusted.

in the quantity of steam generated in relation to the amount of solid waste combusted. The quantity of heat energy generated when solid waste is combusted depends directly on the amount of solid waste combusted for a constant calorific value of the solid waste. Equation (16) indicates that the greater the amount of solid waste combusted the greater the quantity of heat released, hence, the higher the furnace temperature and vice versa. The high furnace temperature thereby influences the quantity of steam generated in the boiler. Numerical simulation and analysis carried out with seven different amounts of solid waste show that, for the chosen design specifications, the quantity of steam generated increases with increase in the amount of solid waste combusted.

Ultimate analysis of a waste stream need to be performed before the theoretical/actual amount of air required to combust the waste stream can be determined. The ultimate analysis of municipal solid waste from Port Harcourt Metropolis was carried out by [16] and the values are presented in Table 2 . Benin 
and Port Harcourt are cities with similar culture and from the same geographical location in Nigeria; it is assumed that both cities have similar composition of municipal solid waste stream. Hence, these values can reasonably be assumed for municipal solid waste from Benin Metropolis.

The steam produced in the boiler may be utilized to generate electricity in a steam turbine generator. Several assumptions were made to account for losses in the turbine and alternator during the numerical calculations. Results from the analysis reveal that about 1.4MW can be generated from the combustion of 3.6ton/hr of solid waste, indicating that, based on the design specifications, about $20.7 \mathrm{MW}$ of electrical power could be generated from the solid waste generated per day in Benin Metropolis. US Energy [22] has published data concerning the amount of fuel that can be efficiently used to generate $1 \mathrm{kWh}$ of electricity. For the case of solid fuel like coal, $0.13104 \mathrm{~kg} / \mathrm{s}$ of it can be used to generate $1 \mathrm{MW}$ of electricity. With the epileptic power supply in Nigeria, this quantity of electrical power would complement that generated in the country. Such a process of energy recovery from waste will contribute to waste management in Benin Metropolis as about $14 \%$ of the daily generated solid waste would have been converted to energy thereby reducing the volume of solid waste left for disposal.

\section{CONCLUSION}

This paper presents a thermal analysis of a small-scale steam boiler with feedstock from combustible solid waste for electrical power generation. Energy balance relations were derived and analysed based on the design specifications. Results from the analysis show that the calorific value of the solid waste varies with the percentage of moisture content of the combustible solid waste, and that the quantity of steam generated varies with the amount of solid waste combusted. However, a calorific value of $17.49 \mathrm{MJ} / \mathrm{kg}$ obtained at a moisture content of $10 \%$ was used for analysis in this work. This indicated that about $3.437 \mathrm{~kg} / \mathrm{s}$ of steam at $20 \mathrm{bar}$ and $400^{\circ} \mathrm{C}$ can be obtained from the combustion of $3.6 \mathrm{ton} / \mathrm{hr}$ of solid waste. The produced steam can be utilized for electrical power generation and, about $1.4 \mathrm{MW}$ of electrical power was obtained from calculation. It was observed that the process of combusting solid waste with energy recovery reduces the waste stream available for disposal by about $14 \%$.

\section{REFERENCES}

[1] World Bank. "Towards a Sustainable Energy Future for All". www.worldbank.org/ content/ dam/worldbank/document/SDN/energy-20130281-2.pdf, Accessed on November 10, 2015.

[2] International Renewable Energy Agency. "Doubling the Global Share of Renewable Energy, A Road Map to 2030". https://www.irena.org/ DocumentDownloads/Publications/IRENA\%20RE MAP $\quad \% 202030 \% 20$ working\%20paper.pdf, Accessed on April 7, 2016.

[3] UNIDO: "Renewable Energy Technologies" https://www.unido.org/fileadmin/media/documen ts/pdf/EEU Training Package/Module7.pdf Accessed on April 10, 2016.

[4] Antonia, V.H., Timothy, E.L. and Daniel, M.K. (2001)." Renewable Energy Sources". www.eolss.com, Accessed on January 5, 2016

[5] U.S. Department of Energy. "Federal Energy Management Program". www://energy.gov/eere/ femp/ federal-energy-management-program, Accessed on December 2, 2015.

[6] Chang, A.C., Chang, H., Lin, F., Lin, K., Chen, C. "Biomass Gasification for Hydrogen Production". International Journal of Hydrogen Energy, Vol. 36, 2011, pp. 14252-14260.

[7] Wang, Q.C. and Luo, Y.H. "A Multifunctional Laboratory Fixed-Bed for Experimental Simulation of Chain-Grate Boiler". Asia-Pacific Power and Energy Engineering Conference, 2010, pp. 1-4.

[8] Swedish Waste Management. "Towards a Greater Future with Sweden Waste-to-Energy: The World's Best Example", 2010. www.avfallsverige.se/ fileadmin/uploads/forbranning eng.pdf. Accessed on January 10, 2014.

[9] Ogwueleka, T.C. "Municipal Solid Waste Characteristics and Management in Nigeria", Iranian Journal of Environmental Health Science and Engineering, Vol. 6, 2009, pp. 173-180

[10] Uchendu, C. "Municipal Solid Waste Treatment and Recycling Technologies for Developing Countries: A Typical Nigeria Case Study". Journal of Solid Waste Treatment and Management, Vol. 34, 2008, pp. 127-135.

[11] IEA, (2011).“Nigeria Renewable Energy Master Plan". $\quad$ www.iea.org/policiesandmeasures/pams/ nigeria/name-24808-en.php? Accessed on February $5,2015$.

[12] Igbinomwanhia, D.I. and E.N Ohwovoriole. A Study of the Solid Waste Chain in Benin Metropolis, Nigeria, Journal of Applied Sciences and Environmental Management, vol. 15, Number 4, 2011, pp 589 - 593.

[13] National Pupolation Commission. Population and Housing Census Enumerator's Manual, 2006, Federal Republic of Nigeria, Abuja, Nigeria. 
[14] Basu, P., Kefa, C. and Jestin, L. Boilers and Burners:Design and Theory, Springer, Paperback, New York, 2000.

[15] Coskun, C., Oktay, Z. and Iten, N., A New Approach for Simplifying the Calculation of Flue Gas Specific Heat and Specific Exergy Value Depending on the Fuel Consumption", Energy Journal, Vol. 34, 2009, pp 1898-1902.

[16] Igoni, H. A., Ayotamuno, M.J., Eze, C.L., Ogali, S.O.T. and Probert, S.D. "Municipal Solid Waste in Port Harcourt, Nigeria”, Applied Energy, Vol. 84, 2007, pp 664-670.

[17] Nzihou, J.F., Hamidou, S., Bouda, M., Koulidiati, J., and Segda, B.G. "Using Dulong and Vandralek Formulas to Estimate the Calorific Heating Value of a Household Waste Mode", International Journal of Scientific \& Engineering Research, Vol. 5, Number 1, 2014, pp 1878-1883.
[18] Ganapathy, V. Steam Generators and Waste Heat Boilers for Process and Plant Engineers, CRC Press, Paperback, New York, 2015.

[19] Rogers, G.F.C and Mayhew, Y.R. Thermodynamics and Transport Properties of Fluid, S.I units, $5^{\text {th }}$ edition, Blackwell Publishing, Paperback, England, 1999.

[20] Nag, P.K. Power Plant Engineering, Tata McGrawHill, $3^{\text {rd }}$ edition, New Delhi, 2008.

[21] Turbine Info: All about Turbines. www.turbinesinfo.com/steam-turbine-efficiency/ Accessed on April 30, 2016.

[22] U.S. Energy Information Administration (EIA)."How Much Coal, Natural Gas, or Petroleum is Used to Generate a kilowatthour of Electricity" www.eia.gov/tools/faqs.cfm?id=667\&t $=6$, Accessed on June 2, 2016. 